\begin{tabular}{ll}
\hline \hline MINING AND METALLURGY INSTITUTE BOR & ISSN: 2334-8836 (Štampano izdanje) \\
UDK: 622 & ISSN: 2406-1395 (Online) \\
\hline \hline
\end{tabular}

UDK: 005:502.2(045)=111

doi:10.5937/mmeb1902061V

Danijela Vujić, Darjan Karabašević, ${ }^{* *}$, Mlađan Maksimović, ${ }^{* *}$, Srđan Novaković**

\title{
THE ROLE OF LEADERS IN CREATING AN ORGANIZATIONAL CULTURE THAT FOSTERS THE CONCEPT OF PRESERVATION THE NATURAL RESOURCES
}

\begin{abstract}
Leadership becomes an important topic of research in the organizational theory as it is an essential factor for the success of organizations. Leadership can be understood as a process of influencing followers based on the clear values and beliefs. Organizational culture is largely evolving under the influence of leadership, and the culture of an organization in some segment can also affect the leadership. The efficient organizations in order to survive in increasingly competitive business conditions require a tactical and strategic thinking as well as the creation of a culture by the leader. Vision and mission of the organization can be realized only if the leader creates a culture dedicated to the support of this vision. Bearing in mind that the natural resources are a factor necessary for the functioning of societies in the modern world, the aim of the manuscript was to determine the role that a leader has in creating an organizational culture that fosters the concept of preserving the natural resources.
\end{abstract}

Keywords: leadership; leader, organizational culture, natural resources.

\section{INTRODUCTION}

Leadership as a phenomenon takes a special place in the world and it becomes a highly desirable attribute in a competitive business conditions. Research on the phenomenon of leadership dates back nearly a century [23].

The importance of leadership and leaders is especially important in the modern organizations. Organizations have realized that the leaders contribute to achieve and maintence competitive advantage [7]. For this reason, the focus of organizations that have leaders among the employees is increasing, and that is why the process of recruitment and selection elect people who possess the leadership skills. Leadership is an essential element of functioning of all organizations. Leaders with their own strengths create a confidence in the organization as well as a desire of their followers to achieve the goals of a group or organization. Leadership is directly related to the ability to influence the people's behavior.

Very rapid industrialization as well as the increasing level of industrial production in the world has caused the rapid depletion of natural resources and emergence of environmental problems, which directly affects the environment. For this reason, the entire world is affected by serious environmental problems, so it is increasingly difficult to find a balance between the production and ecology [1]. The basic objective of preservation the natural resources is reflected primarily in the balance of their use. Balance is needed between the exploitation of re-

\footnotetext{
* Military Medical Academy, Crnotravska 17, 11000, Belgrade

** Faculty of Applied Management, Economics and Finance, University Business Academy in Novi Sad, Jevrejska 24, 11000 Belgrade, Serbia.E-mail: mladjan.maksimovic@mef.edu.rs
} 
sources, economic interests, social interests and interests of environmental protection. This implies the use of resources in accordance with the concept of sustainable development, respecting the three essential imperatives on which the very concept is based, ecological imperative, social and economic imperative $[13 ; 16]$.

Leadership is important for the organization. Organizational culture is largely developed under the influence of leadership, and also the culture of an organization in some segment can affect the leadership. The efficient organizations to survive in increasingly competitive business conditions require a tactical and strategic thinking as well as creating a culture by the leaders. Vision and mission of the organization can be realized only if the leader creates a culture dedicated to the support of this vision [20].

Based on the above, the aim of this paper is to examine the role of leaders in creating an organizational culture that fosters the concept of preservation the natural resources. Accordingly, the manuscript is structured as follows: Section 1 presents the introduction; Section 2 presents a literature review; Section 3 presents the materials and methods while Section 4 presents the results of research with discussion. The final conclusions were given at the end of the paper.

\section{LITERATURE REVIEW}

Leadership is the ability to focus the group on the organization's vision and goals. It can be said that it represents one of the managerial features of a company or organization that interacts with the employees and which has a major impact on the organization's turnover rate. Without leadership, achieving tasks and achievements is impossible [17].

There are different approaches when defining leadership, one of the more interesting approaches proposed by Bass and Stogdill [4] in which they see the leadership with a particular emphasis on the group processes. From this perspective, i.e., the point of view, the leader is the initiator and center of changes and activities in one group, thereby consolidating the will of the group. In other definitions of leadership, the leader is viewed from the perspective of personality, so the leadership is seen as a combination of special characteristics that the individual possesses and which allow him to impose the tasks on others. The rest of the definitions refer to the leadership in a form of activities or behaviors, in the sense that the leadership consists of all activities the leader does to bring about changes in the group. Leadership implies the attitude, leading an organization or some of its work in a new direction, problem solving, creativity, launching the new programs, building the organizational structures and improving the quality in an organization [3].

From the standpoint of classical theorists of organizational behavior, the leadership is viewed from the point where a leader leads followers toward fulfilling organizational objectives. So Davis and Gardner [9] consider the leadership as a human factor that connects members of the group and motivates them to achieve the goals. On the other hand, a similar definition is proposed later by Bass and Bass [3], where they emphasize that leadership can turn the followers, creates a vision of the goals that need to be fulfilled, and where followers are articulating ways of realizing the organizational goals.

The theme of leadership and organizational culture attracts a significant attention and is increasingly becoming the subject of researchers' interest. Most of the research interests for the two areas are based on explicit and implicit claims that the leadership and culture are linked to the organizational performance.

Leadership is a highly desirable attribute in the modern and increasingly competitive business conditions. Leaders believe in their own strengths and create the enthusiasm in the organization as well as the aspiration of the followers in order to achieve the goals of the group or organization. Near the "real" 
leaders, the employees feel more competent and safer. Leadership is also directly related to the ability to influence the people's behavior.

Janićijević [12] stands the view that organizational culture represents the phenomenon of behavior in the organization, i.e. organizational behavior, and that it marked the area of management in the last decade of the XX and the first decade of the XXI century. Numerous researches in the field of organizational culture confirm the role of leaders in creating and maintaining a certain type of culture in organizations [20]. On the other hand, Hennessey [11] indicates the importance of understanding and working within a culture as a prerequisite for a successful leadership.

One of the approaches to discover the relationship between the organizational culture and leadership is to examine how culture is conceived in the organizational theory. Smircich [22] points out two approaches to the study of organizational culture: culture as an organizational variable and culture that is seen as something that can be manipulated. According to Brown [6], organizational culture is defined as "a system of assumptions, values, norms and attitudes manifested through symbols, which members of one organization developed and adopted through a shared experience and which helps them to determine the meaning of the world that surrounds them and how to behave in it" [12].

Fishman and Kavanaugh [10] suggest that the culture of an organization and the way people respond to certain changes and innovations significantly shape the behavior of the leaders. Kavanaugh and Ashkanasy [14] emphasize the view that the role of leaders is important in the process of creating and maintaining a certain type of organizational culture; however, Bass and Avolio [2] state that a particular culture is a prerequisite for the leadership success and point to a mutual relationship between then leadership and organizational culture, that is, the organizational culture and leadership are intertwined.

In his research, Schein [20] thoroughly examined the concepts of organizational culture and leadership, and he also expressed the view that the organizational culture and leadership are two sides of the same coin and can not be understood by themselves. Also, leadership as a process is not separated from a wider situational context in which the leadership takes place, unless a culture supports the leaders, in which case leadership based on common values is not possible. Therefore, culture determines a large part of what the leaders are doing and how they do it [18].

Lately, the link between the organizational culture and leadership has been increasingly mentioned as the basic postulates for creating a sustainable organization. In his research, Baumgartner [5] examines the impact of organizational culture and leadership on creation a viable corporation, and points out that the organizations have a great importance in creating sustainable communities. The extent to which the concept of sustainable development will be applied depends on the leader in an organization as well as the organizational culture.

The culture of one group changes over time and is the result of the most common change in various influential factors such as the business environment, leadership, management practice and formal and informal socialization processes [24]. Organizations face the challenge of applying the concept of sustainable development; however, this is possible with the active role of the leader, which Schmidheiny confirms in his research [21].

Roorda [19] in its extensive research examines the key competences of sustainable development that are an essential step for implementing the concept of sustainable development. It also notes that the emotional intelligence of the leader represents a significant competence necessary for the implementation of concept itself, among other, 
also are mentioned competencies such as the responsibilities, system orientations, future orientations and action skills.

Creating an organizational culture and initiating change in the organization almost always starts from the leader. So, the leaders are those who initiate changes in the organization and who have an impact on creation an organizational culture that will respect the concepts of sustainable development.

\section{MATERIALS AND METHODS}

Research on the role of leaders in creating an organizational culture that fosters the concept of preservation the natural resources was carried out in the period from 15.05.2017 - 30.06.2017. The research includes four economic entities on the territory of Belgrade who, in addition to their regular daily work activities, respect the principles of sustainable development and maximally care about the preservation of natural resources. A survey questionnaire was used as a research instrument. The research was anonymous, while a total of 300 questionnaires were distributed. The number of validly filled questionnaires relevant to the research is 260 , which represents $86.66 \%$ of respondents. The response level and validly filled questionnaires is expected and corresponds to the results that are recommended in the literature [8; 15].

In addition to the basic demographic characteristics, such as gender, age, education, respondents evaluated the following statements using the five-step Likert scale with grades of 1 (I do not agree at all) to 5 (I totally agree):

- The leader in my organization provides the greatest contribution in creating an organizational culture and demonstrates how employees should behave in terms of preserving natural resources.

- The leader in my organization directs followers to use resources respecting the principles of savings and host behavior.
- The leader in my organization, by his own example, demonstrates the use of resources, respecting the principles of savings and host behavior.

- The leader in my organization creates a desirable way for others to revitalize the values and reliability of the principles of preserving natural resources.

- In my organization, the leader nurtures values in terms of preserving natural resources.

- The leader in my organization shows the conformity of my beliefs and actions regarding the creation of an organizational culture aimed at preserving natural resources.

- Employees in the organization guided by the action of the leader align their behavior towards the conservation of natural resources.

- My leader possesses the competencies necessary for creating an organization that in its focus has the preservation of natural resources.

- The leader in my organization, with his attitudes and behaviors, has an impact on raising the environmental awareness of employees.

- The leader in my organization realistically sees reality, assesses the current situation of reality, and makes a decision in the direction of preserving natural resources.

Factor analysis was used to process the results, which is currently one of the most common analyzes of multivariate techniques that has the following goals:

- To identify and understand the basic idea of common characteristics for a number of variables, and

- To reduce the number of variables in the analysis when there are a number of variables, where some of them overlap and have similar meanings or behavior.

The basic objective of factor analysis is that on the basis of mutual variation between the variables that are manifested in the analysis determine a smaller number of varia- 
bles (factors) that explain this so-called cognition between the perceived variables.

In order for factor analysis to be effective, there must be a minimal matching of the variables in its meaning. In this case, a pattern can be detected in the behavior of the variable, that is, the basic idea or factor.

\section{RESEARCH RESULTS AND DISCUSSION}

The research was attended by the total number of respondents from all four subjects, $47.86 \%$ of male respondents and $52.14 \%$ of female respondents. Then, out of the total number of respondents from all four companies / entities, $10.71 \%$ of respondents were aged 18 to 24 years; $15.71 \%$ of respondents aged 25 to 30 years; $32.86 \%$ of respondents aged 31 to 45 years; $27.86 \%$ of respondents aged 46 to 60 years and $12.86 \%$ of respondents were 60 years old and above. Out of the total number of respondents, there were $61.43 \%$ of those with secondary education; $35.0 \%$ of those with higher education and $3.57 \%$ of those with completed faculty, and according to the status of employment in the organization for all four economic entities, there were $99.29 \%$ of employees and $0.71 \%$ of leaders.

When it comes to creating an organizational culture that fosters the concept of preserving natural resources, the respondents gave the highest average grade (4.20) for conclusion that the leader in my organization realistically sees reality, assesses the current situation of reality and makes a decision in the direction of preserving natural resources, with the standard deviation 0.670 . While the lowest average score (3.80) was attributed to the claim that the organization's leader directs followers towards the using of resources, respecting the principles of savings and host behavior with the standard deviation of 0.648 .

Table 1 Correlation matrix between variables

\begin{tabular}{|c|c|c|c|c|c|c|c|c|c|c|c|}
\hline & & Q_1 & Q_2 & Q_3 & Q_4 & Q_5 & Q_6 & Q_7 & Q_8 & Q_9 & Q_10 \\
\hline \multirow{10}{*}{ 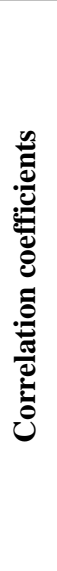 } & Q_1 & 1.000 & 0.180 & 0.354 & 0.252 & 0.241 & 0.277 & 0.236 & 0.186 & 0.087 & 0.192 \\
\hline & Q_2 & 0.180 & 1.000 & 0.367 & 0.293 & 0.308 & 0.194 & 0.135 & 0.192 & 0.154 & -0.007 \\
\hline & Q_3 & 0.354 & 0.367 & 1.000 & 0.464 & 0.334 & 0.225 & 0.207 & 0.193 & 0.203 & 0.043 \\
\hline & Q_4 & 0.252 & 0.293 & 0.464 & 1.000 & 0.600 & 0.208 & 0.329 & 0.288 & 0.237 & 0.137 \\
\hline & Q_5 & 0.241 & 0.308 & 0.334 & 0.600 & 1.000 & 0.307 & 0.459 & 0.443 & 0.368 & 0.244 \\
\hline & Q_6 & 0.277 & 0.194 & 0225 & 0208 & 0.307 & 1.000 & 0.401 & 0.363 & 0326 & 0.293 \\
\hline & Q_7 & 0.236 & 0.135 & 0.207 & 0.329 & 0.459 & 0.401 & 1.000 & 0.376 & 0.423 & 0.355 \\
\hline & Q_8 & 0.186 & 0.192 & 0.193 & 0.288 & 0.443 & 0.363 & 0.376 & 1.000 & 0.548 & 0.399 \\
\hline & Q_9 & 0.087 & 0.154 & 0.203 & 0.237 & 0.368 & 0.326 & 0.423 & 0.548 & 1.000 & 0.525 \\
\hline & Q_10 & 0.192 & -0.007 & 0.043 & 0.137 & 0.244 & 0.293 & 0.355 & 0.399 & 0.525 & 1.000 \\
\hline
\end{tabular}

Table 1 shows the strength of the relationship between the variables from the analysis through the correlation coefficient, which indicates the relationship between variables from the questionnaire, i.e. those variables that are related to creating an or ganizational culture that fosters the concept of preservation the natural resources. Correlation coefficients range from -1 to +1 . The dependency coefficient level between the variables for this analysis is over \pm 0.3 . Table shows that there are the correlation coe- 
fficients that are greater than 0.3 and that the following analysis is justified; also, the obtained data are suitable for a decisionmaking.
The methodology of the analysis indicates the need for another analysis in which it is approached with the following tests to even more accurately assess the significance of the use of the passing test.

Table 2 Passing test for the main component analysis

\begin{tabular}{|l|r|r|}
\hline \multicolumn{2}{|c|}{ Kaiser-Meyer-Olkin Measure of Sampling Adequacy } & 0.807 \\
\hline \multirow{3}{*}{ Bartlett's Test of Sphericity } & Approx. Chi-Square & 373.611 \\
\cline { 2 - 3 } & df & 45 \\
\cline { 2 - 3 } & Probability & 0.000 \\
\hline
\end{tabular}

The value of the Kaiser-Meyer-Olkin Measurement of the Sampling Adequacy test is greater than 0.5 while the other Bartlett's Test of Sphericity is significant at an error level of 0.000 . The obtained values of conducted tests for the analysis of the main components show that the data, used for the survey or scale by which the respondents were surveyed, are justified as a method of measuring this phenomenon.
After previous checks, the methodology suggests calculating the common variation that variables have among themselves through the so-called extracted variance. The maximum variation tends to number one, which means that the values closer to it are more common in terms of variation with other variables.

Table 3 Communalities explained by variance of variables

\begin{tabular}{|l|c|c|}
\hline \multicolumn{1}{|c|}{ Indicators } & Initial & $\begin{array}{c}\text { Extracted } \\
\text { variance }\end{array}$ \\
\hline $\begin{array}{l}\text { 1. The leader in my organization provides the greatest contribution in } \\
\text { creating an organizational culture and demonstrates how employees should } \\
\text { behave in terms of preservation the natural resources }\end{array}$ & 1.000 & 0.287 \\
\hline $\begin{array}{l}\text { 2. The leader in my organization directs followers to use resources } \\
\text { respecting the principles of savings and host behavior }\end{array}$ & 1.000 & 0.428 \\
\hline $\begin{array}{l}\text { 3. The leader in my organization, by his own example, demonstrates the use of } \\
\text { resources, respecting the principles of savings and host behavior }\end{array}$ & 1.000 & 0.599 \\
\hline $\begin{array}{l}\text { 4. The leader in my organization creates a desirable way for others to } \\
\text { revitalize the values and reliability of the principles of preservation } \\
\text { the natural resources }\end{array}$ & 1.000 & 0.582 \\
\hline $\begin{array}{l}\text { 5. In my organization, the leader nurtures values in terms of preservation } \\
\text { the natural resources }\end{array}$ & 1.000 & 0.580 \\
\hline $\begin{array}{l}\text { 6. The leader in my organization shows the conformity of my beliefs and actions } \\
\text { regarding the creation of an organizational culture aimed at preserving natural } \\
\text { resources }\end{array}$ & 1.000 \\
\hline $\begin{array}{l}\text { 7. Employees in the organization guided by the action of the leader align their } \\
\text { behavior towards the conservation of natural resources }\end{array}$ & 1.000 & 0.374 \\
\hline $\begin{array}{l}\text { 8. My leader possesses the competencies necessary for creating an } \\
\text { organization that in its focus has the preservation of natural resources }\end{array}$ & 1.000 & 0.496 \\
\hline $\begin{array}{l}\text { 9. The leader in my organization, with his attitudes and behaviors, has an } \\
\text { impact on raising the environmental awareness of employees }\end{array}$ & 1.000 & 0.564 \\
\hline $\begin{array}{l}\text { 10. The leader in my organization realistically sees reality, assesses the cur- } \\
\text { rent situation of reality, and makes a decision in the direction of preserva- } \\
\text { tion the natural resources }\end{array}$ & 1.000 & 0.642 \\
\hline Extraction Method: Principal Component Analysis & 0.617 \\
\hline
\end{tabular}

Extraction Method: Principal Component Analysis. 
Between the indicators there is a common variability explained by absolute variation over variance. The stated amount of variance (saturation of the component) can be maximal up to number one to correlate with a larger number of indicators.

The purpose of the analysis is to determine the indicators that simultaneously vary and where in this way they also correlate to a new dimension that actually forms a group of common factors that affect a particular phenomenon. Therefore, this analysis further implies the use of a test that calculates the total variability or quantity. By further using the Kaiser's criteria, through which the total variability is extracted and which is downgraded by a score higher than the number one.

Which indicators will remain in the analysis, it is decided after applying the socalled factor space rotation in order to facilitate the interpretation of the results. Using orthogonal rotation through one of the default (Virimax) will show the indicators that vary with high variance values in the new impact factors.

Table 4 The totally explained variability of analysis of the main components

\begin{tabular}{|c|c|c|c|c|c|c|}
\hline \multirow{2}{*}{ 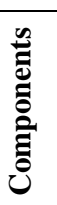 } & \multicolumn{3}{|c|}{ Basic equivalents of variance } & \multicolumn{3}{|c|}{$\begin{array}{c}\text { Extracted summarized variability of } \\
\text { components }\end{array}$} \\
\hline & Total & $\begin{array}{c}\% \text { from } \\
\text { variance }\end{array}$ & $\underset{\%}{\text { Cumulative }}$ & Total & $\begin{array}{c}\% \text { from } \\
\text { variance }\end{array}$ & $\underset{\%}{\text { Cumulative }}$ \\
\hline 1 & 3.664 & 3.635 & 36.635 & 3.664 & 36.635 & 36.635 \\
\hline 2 & 1.506 & 15.059 & 51.694 & 1.506 & 15.059 & 51.694 \\
\hline 3 & 0.941 & 9.413 & 61.107 & & & \\
\hline 4 & 0.805 & 8.047 & 69.154 & & & \\
\hline 5 & 0.722 & 7.215 & 76.369 & & & \\
\hline 6 & 0,586 & 5.857 & 82.226 & & & \\
\hline 7 & 0.568 & 5.684 & 87.91 & & & \\
\hline 8 & 0.508 & 5.075 & 92.985 & & & \\
\hline 9 & 0.362 & 3.616 & 96.601 & & & \\
\hline 10 & 0.34 & 3.399 & 100 & & & \\
\hline
\end{tabular}

Table 4 shows the number of common extracted factors, the possible values associated with these factors, the percentage of total variation explained by each factor and the cumulative percentage of total variance explained by the factors. Using the criterion for retaining only those factors with possible values of 1 or more, in this case, two factors are retained for rotation. These two factors explain $36.64 \%$ and $15.06 \%$ of the total variance, which together account for $51.7 \%$ of cases with which variance of indicators correlates.

Figure 1 shows a diagram of a factor transitions showing a clear fracture point behind another component (factor). In further discussion of the research results, two factors (factors) are retained that were obtained by the factor analysis, which is considered as two dimensions, or subscales. The first component explains $36.6 \%$ variation and the other $15.1 \%$ of variation. 


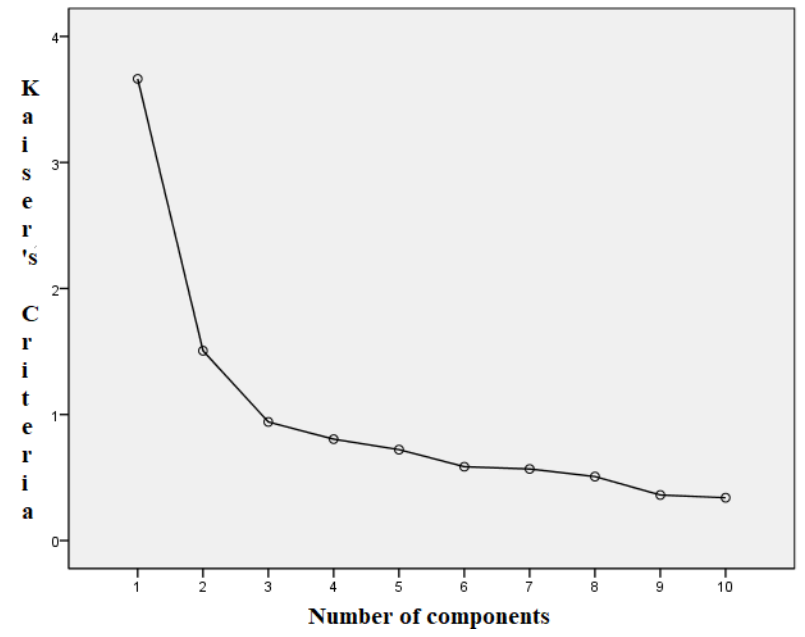

Figure 1 Skater diagram

The methodology of the analysis involves a correlation matrix for two factors, to determine which of the variables has the highest coefficient correlating with the factor - which means closer to the number one.

Table 5 Matrix of original components with its saturation based on each indicator

\begin{tabular}{|l|c|c|}
\hline & \multicolumn{2}{|c|}{ Component } \\
\cline { 2 - 3 } & $\mathbf{1}$ & $\mathbf{2}$ \\
\hline $\begin{array}{l}\text { 1. The leader in my organization provides the greatest contribution in } \\
\text { creating an organizational culture and demonstrates how employees } \\
\text { should behave in terms of preservation the natural resources }\end{array}$ & 0.459 & 0.277 \\
\hline $\begin{array}{l}\text { 2. The leader in my organization directs followers to use resources re- } \\
\text { specting the principles of savings and host behavior }\end{array}$ & 0.427 & 0.496 \\
\hline $\begin{array}{l}\text { 3. The leader in my organization, by his own example, demonstrates the } \\
\text { use of resources, respecting the principles of savings and host behavior }\end{array}$ & 0.537 & 0.557 \\
\hline $\begin{array}{l}\text { 4. The leader in my organization creates a desirable way for others to } \\
\text { revitalize the values and reliability of the principles of preservation the } \\
\text { natural resources }\end{array}$ & 0.643 & 0.411 \\
\hline $\begin{array}{l}\text { 5. In my organization, the leader nurtures values in terms of preservation } \\
\text { the natural resources }\end{array}$ & 0.744 & 0.164 \\
\hline $\begin{array}{l}\text { 6. The leader in my organization shows the conformity of my beliefs and } \\
\text { actions regarding the creation of an organizational culture aimed at } \\
\text { preservation the natural resources }\end{array}$ & 0.596 & -0.135 \\
\hline $\begin{array}{l}\text { 7. Employees in the organization guided by the action of the leader align } \\
\text { their behavior towards the conservation of natural resources }\end{array}$ & 0.676 & -0.200 \\
\hline $\begin{array}{l}\text { 8. My leader possesses the competencies necessary for creating an organi- } \\
\text { zation that in its focus has the preservation of natural resources }\end{array}$ & 0.688 & -0.299 \\
\hline $\begin{array}{l}\text { 9. The leader in my organization, with his attitudes and behaviors, has an } \\
\text { impact on raising the environmental awareness of employees }\end{array}$ & 0.668 & -0.443 \\
\hline $\begin{array}{l}\text { 10. The leader in my organization realistically sees reality, assesses the } \\
\text { current situation of reality, and makes a decision in a direction of } \\
\text { preservation the natural resources }\end{array}$ & 0.533 & -0.577 \\
\hline
\end{tabular}


For easier interpretation, the following is the rotation of component saturation, but only in the case that the first and second factors are not in a great correlation.

Table 6 Matrix of rotated components with its saturations based on each indicator of the first component

\begin{tabular}{|l|c|}
\hline \multicolumn{1}{|c|}{ Indicators } & $\begin{array}{c}\text { First } \\
\text { component }\end{array}$ \\
\hline $\begin{array}{l}\text { 1. The leader in my organization provides the greatest contribution in } \\
\text { creating an organizational culture and demonstrates how employees should } \\
\text { behave in terms of preservation the natural resources }\end{array}$ & $\mathbf{0 . 1 7 1}$ \\
\hline $\begin{array}{l}\text { 2. The leader in my organization directs followers to use resources respecting } \\
\text { the principles of savings and host behavior }\end{array}$ & $\mathbf{0 . 0 0 6}$ \\
\hline $\begin{array}{l}\text { 3. The leader in my organization, by his own example, demonstrates the use of } \\
\text { resources, respecting the principles of savings and host behavior }\end{array}$ & $\mathbf{0 . 0 5}$ \\
\hline $\begin{array}{l}\text { 4. The leader in my organization creates a desirable way for others to revitalize the } \\
\text { values and reliability of the principles of preservation the natural resources }\end{array}$ & $\mathbf{0 . 2 2 5}$ \\
\hline $\begin{array}{l}\text { 5. In my organization, the leader nurtures values in terms of preserving natural } \\
\text { resources }\end{array}$ & $\mathbf{0 . 4 6 2}$ \\
\hline $\begin{array}{l}\text { 6. The leader in my organization shows the conformity of my beliefs and actions } \\
\text { regarding the creation of an organizational culture aimed at preservation the } \\
\text { natural resources }\end{array}$ & $\mathbf{0 . 5 4 2}$ \\
\hline $\begin{array}{l}\text { 7. Employees in the organization guided by the action of the leader align their } \\
\text { behavior towards the conservation of natural resources }\end{array}$ & $\mathbf{0 . 6 4 5}$ \\
\hline $\begin{array}{l}\text { 8. My leader possesses the competencies necessary for creating an organization } \\
\text { that in its focus has the preservation of natural resources }\end{array}$ & $\mathbf{0 . 7 1 9}$ \\
\hline $\begin{array}{l}\text { 9. The leader in my organization, with his attitudes and behaviors, has an impact on } \\
\text { raising the environmental awareness of employees }\end{array}$ & $\mathbf{0 . 7 9 6}$ \\
\hline $\begin{array}{l}\text { 10. The leader in my organization realistically sees reality, assesses the current } \\
\text { situation of reality, and makes a decision in a direction of preservation the } \\
\text { natural resources }\end{array}$ & $\mathbf{0 . 7 7 9}$ \\
\hline
\end{tabular}

It is seen from Table 6 that after the matrix development of rotated components with its saturations based on each indicator of the first component (factors), four variables are grouped into the first component that we will name as:

\footnotetext{
- Existence of real attitudes in accordance with knowledge and action.
}

It is seen from Table 7 that after the matrix development of rotated components with its saturations based on each indicator of the second component (factors), also four variables are grouped into the second component that we will name as:

\footnotetext{
- Creativity as an example to the fo-llowers for not giving up the set objective.
} 
Table 7 Matrix of rotated components with its saturations based on each indicator of the second component

\begin{tabular}{|l|r|}
\hline \multicolumn{1}{|c|}{ Indicators } & $\begin{array}{c}\text { Second } \\
\text { component }\end{array}$ \\
\hline $\begin{array}{l}\text { 1 The leader in my organization provides the greatest contribution in creating } \\
\text { an organizational culture and demonstrates how employees should behave } \\
\text { in terms of preservation the natural resources }\end{array}$ & $\mathbf{0 . 5 0 8}$ \\
\hline $\begin{array}{l}\text { 2. The leader in my organization directs followers to use resources respecting } \\
\text { the principles of savings and host behavior }\end{array}$ & $\mathbf{0 . 6 5 4}$ \\
\hline $\begin{array}{l}\text { 3. The leader in my organization, by his own example, demonstrates the use } \\
\text { of resources, respecting the principles of savings and host behavior }\end{array}$ & $\mathbf{0 . 7 7 2}$ \\
\hline $\begin{array}{l}\text { 4. The leader in my organization creates a desirable way for others to revital- } \\
\text { ize the values and reliability of the principles of preservation the natural } \\
\text { resources }\end{array}$ & $\mathbf{0 . 7 2 9}$ \\
\hline $\begin{array}{l}\text { 5. In my organization, the leader nurtures values in terms of preservation the } \\
\text { natural resources }\end{array}$ & $\mathbf{0 . 6 0 6}$ \\
\hline $\begin{array}{l}\text { 6. The leader in my organization shows the conformity of my beliefs and } \\
\text { actions regarding the creation of an organizational culture aimed at preser- } \\
\text { vation the natural resources }\end{array}$ & $\mathbf{0 . 2 8 2}$ \\
\hline $\begin{array}{l}\text { 7. Employees in the organization guided by the action of the leader align } \\
\text { their behavior towards the conservation of natural resources }\end{array}$ & $\mathbf{0 . 2 8 4}$ \\
\hline $\begin{array}{l}\text { 8. My leader possesses the competencies necessary for creating an organiza- } \\
\text { tion that in its focus has the preservation of natural resources }\end{array}$ & $\mathbf{0 . 2 1 6}$ \\
\hline $\begin{array}{l}\text { 9. The leader in my organization, with his attitudes and behaviors, has an } \\
\text { impact on raising the environmental awareness of employees }\end{array}$ & $\mathbf{0 . 0 9 3}$ \\
\hline $\begin{array}{l}\text { 10. The leader in my organization realistically sees reality, assesses the cur- } \\
\text { rent situation of reality, and makes a decision in a direction of preserving } \\
\text { natural resources }\end{array}$ & $\mathbf{- 0 . 0 9 7}$ \\
\hline
\end{tabular}

\section{CONCLUSION}

Leadership becomes a significant topic in the organizational theory and a necessary factor for the success of any business endeavor. Leader in the organization plays a significant role reflected through: determining and realizing goals, motivating and supporting the followers towards achieving goals, supporting unity and empowering group values. Leaders always strive to work within the framework of the roles that require change, while maintaining continuity in meeting the needs of constituents or stakeholders (stakeholders).

Based on the conducted research, it can be concluded that the employees in the organization are always guided by the actions of their leader, and on the case of the organizations that participated in this survey, the employees permanently align their behavior in a direction of preservation the natural resources. Leaders in such organizations that are focused on preservation the natural resources must possess the competences necessary for creating such organizations with a focus on preserving natural resources. By its attitudes and behavior, the leader has an impact on raising the environmental awareness of employees. Therefore, the leader must always realistically see reality, assess the situation before making any decision, and the decision should be directed towards the preservation of natural resources. The leader in the specific organizations directs followers towards using of resources, respecting the principles of savings and host behavior. Therefore, on a personal example, 
he must always demonstrate this host behavior because it creates a desirable way for others to revitalize the values and reliability of the principles of preservation the natural resources. Naturally, the leader would have to preserve, after creating the desired paths, for as long a period as possible and to nourish the values that lead to the preservation of natural resources.

Also, research shows that a leader in the organization mainly deals with people, their behavior and knowledge, their potentials and abilities and their stimuli and results. The leader directs his communication towards rational use of resources, and when employees give an opinion, the leader always asks and what others think. The leader in the organization actively communicates and shares information on the rationalization of resource use and always consults with the followers and provides guidance on resource preservation. Employees in the organization give an open and honest feedback to each other, making it easier for the leader to cooperate with all stakeholders in order to meet the mutual needs of organization. Aware of its role and importance, the leader always has an influence on an organizational culture that is focused on preservation the natural resources and always seeks for ideas and opinions that are not always in a line with his personal, in that way he establishes the values that strengthen and support the business ideas.

\section{REFERENCES}

[1] Antoci A., Galeotti M., \& Sordi S. (2018). Environmental Pollution as Engine of Industrialization. Communications in Nonlinear Science and Numerical Simulation, 58, 262-273.

[2] Bass B. M., \& Avolio B. J. (1993). Transformational Leadership and Organizational Culture. Public Administration Quarterly, 112-121.
[3] Bass B.M., \& Bass R. (2009). The Bass Handbook of Leadership: Theory, Research, and Managerial Applications. Simon and Schuster.

[4] Bass B. M., \& Stogdill R. M. (1990). Bass \& Stogdill's Handbook of Leadership: Theory, Research, and Managerial Applications. Simon and Schuster.

[5] Baumgartner R. J. (2009). Organizational Culture and Leadership: Preconditions for the Development of a Sustainable Corporation. Sustainable Development, 17(2), 102-113.

[6] Brown A. (1998). Organizational Culture, Person Education, Edinburgh.

[7] Bryman A. (1996). Leadership in Organizations. Handbook of Organization Studies, 276, 292.

[8] Das A., Handfield R.B., Calantone R.J., \& Ghoch S. (2000). A Contigent View of Quality Management: The Impact of International Competition on Quality. Decision Sciences, 31, 649-690.

[9] Davis W.D., \& Gardner W. L. (2004). Perceptions of Politics and Organizational Cynicism: An Attributional and Leader-Member Exchange Perspective, The Leadership Quarterly, 15(4), 439-465.

[10] Fishman N., \& Kavanaugh L. (1989). Searching for Your Missing Quality Link. Journal for Quality and Participation, 12(4), 28-32.

[11] Hennessey Jr, J.T. (1998). "Reinventing" Government: Does Leadership Make the Difference?. Public Administration Review, 522-532.

[12] Janićijević N. (2011), The Effect of Leadership on the Organizational Culture. Ekonomika preduzeća, 59(56), 215-226 (in Serbian) 
[13] Karabašević D., Paunkovic J., \& Stanujkic D., (2016). Ranking of Companies According to the Indicators of Corporate Social Responsibility Based on SWARA and ARAS Methods, Serbian Journal of Management, 11(1), 43-53.

[14] Kavanagh M. H., \& Ashkanasy N. M. (2006), The Impact of Leadership and Change Management Strategy on Organizational Culture and Individual Acceptance of Change During a Merger, British Journal of Management, 17(S1).

[15] Kayank H. (2003). The Relationship Between Total Quality Management Practices and Their Effects on Firm Performance. Journal of Operations Management, 21(4), 405-435.

[16] Maksimović M. M., Karabašević D., Brzaković, M., \& Brzaković, P. (2017). The Effects Resulting from the Application of the Concept of the Sustainable Development of Rural Tourism on Stara Planina. Economics of Agriculture, 64(4), 1595-1606.

[17] Mills D. Q. (2005). Leadership: How to Lead, How to Live. MindEdge Press.
[18] Northouse P. G. (2015). Leadership: Theory and Practice, Sage Publications

[19] Roorda N. (2010). Sailing on the Winds of Change: The Odyssey to Sustainability of the Universities of Applied Sciences in the Netherlands (Doctoral Dissertation, Maastricht University).

[20] Schein E. H. (2006). Organizational Culture and Leadership (Vol. 356). John Wiley \& Sons.

[21] Schmidheiny S. (1992). Changing Course: A Global Business Perspective on Development and the Environment (Vol. 1). MIT Press.

[22] Smircich L. (1983). Concepts of Culture and Organizational Analysis. Administrative Science Quarterly, 339-358.

[23] Viitala R. (2004). Towards Knowledge Leadership. Leadership \& Organization Development Journal, 25(6), 528-544.

[24] Wilson A. M. (2001). Understanding Organisational Culture and the Implications for Corporate Marketing. European Journal of Marketing, 35(3/4), 353-367. 